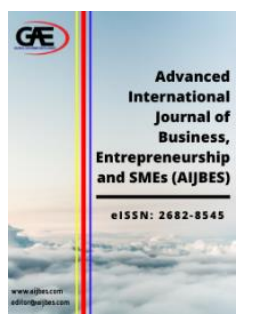

\author{
ADVANCED INTERNATIONAL JOURNAL OF \\ BUSINESS, ENTREPRENEURSHIP AND SMES \\ (AIJBES) \\ www.aijbes.com
}

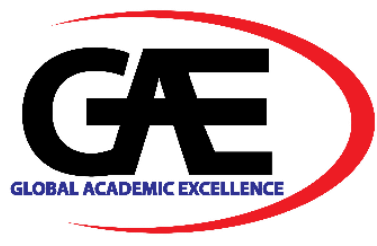

\title{
HOW FASHION INFLUENCER CONTRIBUTES TO CONSUMERS' PURCHASE INTENTION OF UNIVERSITY STUDENT
}

\author{
Tsaniya Athaya Tsarashafa ${ }^{1 *}$, Annisa Rahmani Qastharin ${ }^{2}$ \\ 1 School of Business and Management, Institut Teknologi Bandung, Indonesia \\ Email: tsaniya_athaya@sbm-itb.ac.id \\ 2 School of Business and Management, Institut Teknologi Bandung, Indonesia \\ Email: annisa.rahmani@sbm-itb.ac.id \\ * Corresponding Author
}

\section{Article Info:}

Article history:

Received date: 29.06 .2021

Revised date: 27.07.2021

Accepted date: 18.08.2021

Published date: 02.09.2021

\section{To cite this document:}

Tsarashafa, T. A., \& Qastharin, A. R. (2021). How Fashion Influencer Contributes to Consumers' Purchase Intention of University Student. Advanced International Journal of Business, Entrepreneurship and SMEs, 3 (9), 209-227.

DOI: $10.35631 /$ AIJBES.39015.

This work is licensed under CC BY 4.0

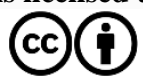

\begin{abstract}
:
Fashion is receiving more attention these days since it has become a continual existence in a person's everyday life, especially for the younger generation as it represents their identity. On the other hand, the dynamic competitive environment of marketing-led fashion brands to put in the excess effort to achieve effective marketing strategies. As social media grew, one of the most effective ways to do it is using influencers in the marketing campaign. Influencer marketing is becoming increasingly popular throughout the world, prompting marketers to consider it an essential component of their marketing strategy. This research determines the factors of fashion influencers that contribute to influencing purchase intention. The variables constructed include trustworthiness, expertise, similarity, likability, and familiarity. Further, consumer attitude is proposed to mediate between trustworthiness, expertise, similarity, likability, and familiarity to purchase intention. The research was conducted using a quantitative approach and analyzed using a regression method through IBM SPSS Statistics. From 234 qualified respondents, the results presented trustworthiness, similarity, familiarity, and likability significantly contribute to purchase intention, and consumers' attitudes towards influencers are proven to be mediate the relationships between independents variables and purchase intention. The findings of the study assist marketers and advertisers in the fashion industry in understanding the elements influencing consumer attitudes about fashion influencers and, as a result, better choose influencers capable of establishing purchase intentions in existing and potential customers.
\end{abstract}

Keywords:

Consumers Attitudes, Fashion Influencers, Influencer Marketing, Purchase Intention, Social Media, Source Of Attractiveness, Source Of Credibility 


\section{Introduction}

Fashion clothing is believed to carry on behavioral and social standards that represent a person's self-identity and social image (Piamphongsant and Mandhachitara, 2008). According to market research conducted by some of the world's leading consulting firms (McKinsey, Deloitte Group, BCG), fashion companies today operate in a highly dynamic competitive environment characterized by rapid changes and growing unpredictability (Gazzola et al., 2020). Consumers select fashion goods based on their personal style and ideals. As a result, fashion businesses must learn how to provide items and experiences that customers will view as distinctive (Pentina et al., 2018). The brands are putting in every effort to develop their brands, attracting customers' attention to the product and building positive associations, not only to influence recall but also to induce trial and, ultimately, to influence purchase decisions (Khatri, 2006).

As the number of people using social media grew, so did marketing trends and techniques, and marketers began to see social media platforms as important avenues for communicating with and interacting with customers (Bianchi et al., 2017). Consumers utilize social media content as a source of clothing inspiration; therefore, these technologies can influence their purchasing decision (Aragoncillo and Orús, 2018). Advances in social media platforms have led to an upward recognition of influencers (Xu and Pratt, 2018). With the growing demands in the fashion industry, consumers are becoming more fashion-conscious, and fashion trends have a strong influence on their purchasing decisions (Lang and Armstrong, 2018) and fashion Influencers (FIs) or fashion leaders are usually in charge of such trends (Park and Kim, 2016). Fashion influencers are social media personalities with a large following who create fashion content and have the ability to influence their followers' purchasing decisions (Chetioui, 2019). They are regarded as newcomers to the fashion industry because they appeal to customers who have a strong desire for fashionable items (Park and Kim, 2016).

Moreover, the reliability of these influencer recommendations is determined by how consumers perceive it (Johnson et al., 2008). According to a previous study, consumers' opinions and purchasing intentions are positively influenced by credibility (Liljander et al., 2015). Additionally, a consumer tends to accept information given by attractive sources (Kelman, 1961). According to several studies, there is a positive association between the influencers' source of attractiveness and consumers' attitude as well as their purchase intention (Erdogan, 1999).

Within the fashion industry's circumstances, fashion customers, primarily generations $\mathrm{Y}$ and $\mathrm{Z}$, may be increasingly influenced by influencers in the context of the fashion industry (Pate and Adams, 2013). A large proportion of early adopters of new ideas and products are typically represented by university students (Thompson and Thong, 2015). So, university students are a unique community with a sense and concern in fashion in order to point out their identity and build self-esteem within themself through fashion items they use. When they decide to purchase a fashion item, they are likely to seek advice from someone who is known for being fashionable and frequents popular boutiques (Solomon and Rabolt, 2004). University students constantly seek information through fashion leaders or endorsers (Lafferty etal., 2002) to get inspiration for their fashion style. In comparison to celebrity endorsements as a marketing approach, the usage of social media influencers is seen as more reliable, trustworthy, and knowledgeable due to their capacity to establish affinity with customers (Berger et al. 2016), especially for businesses targeting the younger generations. In this situation, marketers and advertisers should be aware that the young consumer depends more on modern media (Cheong 
and Morrison, 2008), on the grounds that they search for real and honest recommendations (Liljander et al., 2015).

This research aims to identify factors that influence consumers' attitudes towards fashion influencers, which subsequently influence purchase intention. Moreover, this research also aim to identify the relationship between consumers' attitude towards the influencer and purchase intention. It allows marketers to better understand which aspects explain attitudes about FIs and which aspects influence consumers' purchase intentions, allowing them to better choose influencers that are capable of establishing purchase intentions among existing and new customers, resulting in an increase in product sales.

\section{Literature Review}

\section{The Concept of Influencer Marketing}

Influencer marketing is a new phenomenon in marketing activities where it identified in previous research by Sudha and Sheena (2017) as "process of identifying and activating individuals who have an influence over a specific target audience or medium, in order to be part of a brand's campaign towards increased reach, sales, or engagement". Influencer marketing could be viewed as an expansion of word-of-mouth yet at a bigger and focusing on a social framework. Furthermore, it could be seen as a way for businesses to expand their audience with a final goal to transform them into loyal customer through trust and credibility, because there is a strong relationship between the influencer and his audience that the influencer maintains (Zainab et al., 2020) where the relationship stems from the influencer making content which is desired by individuals and the audience that is relate with the influencers, which in turn causes the audience to have a certain level of trust towards the influencer marketing's point of views (Sudha and Sheena, 2017). Previous study by TapInfluence (2019) stated that influencer marketing may generate 11 times higher return on investment than other traditional advertising platforms. Within the fashion industries' context, the customers, primarily generations $\mathrm{Y}$ and $\mathrm{Z}$, may be more affected by influencers (Pate and Adams, 2013).

\section{Source Credibility Model}

The two elements within the source of credibility are trustworthiness and expertise (Ratneshwar and Chaiken, 1991). The uniqueness of positive communication from endorsers is that they have the innate capacity to influence their audience to accept the message they are conveying. The information delivered can further enlarge the receiver's knowledge and experience of the product comprehension (Djafarova and Rushworth, 2017). In the fashion industry, fashion influencers have long been viewed as critical to the dissemination of new fashion trends, as they have significant influence over their audience due to their knowledge, expertise, and reputation as trustworthy sources of information (Thakur et al., 2016). Previous studies acknowledge that recommendations and reviews that come from influencers who are perceived as credible would drive a higher purchase intention (Lee et al., 2011).

\section{Trustworthiness}

The trust paradigm in communication indicates the confidence level of the receiver in receiving the information conveyed by Influencer (Nejad, et al., 2014; Ohanian, 1990). Consumers are more inclined to accept a product suggested by a Social Media Influencer if they believe the influencer is trustworthy (Liu et al., 2015). Influencers' credibility determines the expected 
value of the information offered by their product endorsements, therefore they perceived trustworthiness might influence purchase intention (Cheung et al., 2008).

\section{Expertise}

While the perceived degree of skills, practice, or understanding of an endorser is referred to as their expertise (Teng et al., 2014). In this context, expertise refers to an influencer's ability to provide precise and credible information from the beginning of the interaction with the consumer to the increased bond relationship with them (Nejad et al., 2014). Social media influencer interacts with their followers on social media with professional experience, knowledge, and personal insights, allowing them to be seen as an expert in their field and makes their followers feel more dependable to the influencers (Kapitan and Silvera, 2016). Previous study has discovered that expertise has a substantial effect on purchase intention (Thomas and Johnson, 2017).

\section{Source Attractiveness Model}

Source attractiveness refers to the endorser's physical characteristics, such as similarity, familiarity, and likability to their audience (Ohanian, 1990). The source's similarity, familiarity, and likability have an impact on the context of information effectiveness and interaction (Chun et al., 2018). However, Physical attractiveness wasn't the only aspect to consider; other aspects such as creativity skills, personal attributes, lifestyle, and the endorser's capabilities must also be considered (Zafer, 2010).

\section{Similarity}

Similarity is the degree to which individuals share the same demographic background, interests, attitudes, social class, and lifestyle; the "like me" concept has been observed when people engage more frequently with those who are similar (Fanoberova and Kuczkowska, 2016). Nejad et al., (2014) found that consumers pay attention to and interpret information based on their current motivations, attitudes, and interests. Consumers who share a common interest, value, or characteristic with the influencer believed they are more inclined to execute the influencers' views, attitudes, and behaviors (Kelman, 2006).

\section{Familiarity}

Familiarity is recognized as the assumed resemblance to information that is preceded by influencer, and it can be obtained over an exposure (Yi, 2012). Customers are expected to trust the sources they are familiar with and have a relation with, in order to reduce the potential risk in their decision making (Lee and Yurchisin, 2011).

\section{Likability}

Likability indicates the receiver's affection for physical appearance, personal characteristics, and personality of the information source (Teng et al., 2014). Moreover, the affection towards an influencer drives consumers to follow them, much as how consumers follow their fashionable friend; any new interest in any new brands will also impact one's level of affection towards the specific brand which the influencer wears (Colliander and Dahlén, 2011). As a result, the better the likability of a source, the more successful the message will be conveyed, as likability tends to increase attention and message retention (Fanoberova and Kuczkowska, 2016). 


\section{Consumers' Attitudes Towards the Influencer}

Influencer marketing plays an essential part in new products' adoption and dissemination of linked information (Wang, Ting and $\mathrm{Wu}, 2013$ ), as a result it is a crucial component of marketing communications (Tsang and Zhou, 2005). Consumer attitude towards the influencer is highly influenced based on how the influencers convey advertising messages, what kind of visual and verbal information they use while promoting the product (Braatz, 2017). Consumers most likely to like the advertisement that uses positive character, someone who is regarded to be memorable, credible, captivating, and charming (Leather et al., 1994). Essentially, fashion purchasing is a special task that demands more engagement in the details from the consumer (Sudha and Sheena, 2017). It means that when customers purchase things that have been previously recommended by social media influencers, their self-esteem is boosted (Djafarova and Rushworth, 2017).

\section{Purchase Intention}

Consumer purchase intention is formed by a consumer's attitude, evaluation, and external influences, and it is an important component in forecasting behavior of the consumer (Chi, Yeh, \& Tsai, 2011). Purchase intention refers to the possibility that a consumer is inclined or is willing to purchase a specific brand in the future (Huang et al., 2011). The higher the purchase intention is resulting the higher the possibility of the consumer to purchase the product (Schiffman \& Kanuk, 2000). The consumers' purchase behavior has evolved because of the rise of internet usage, it allows consumers to do an online transaction and the way of online purchase is different compared to the traditional way because the consumers are more concerned about the online store and its various components (Dreifaldt and Drennan, 2019). In the previous research, they also stated that consumers experience a certain level of risk when purchasing online, even though internet usage has increased frequently. Especially, in fashion purchasing which require special task that demands more engagement in the details from the consumer (Sudha and Sheena, 2017). Consumers believed that trusted influencers can make the consumer accept their recommendation and change their purchasing decision (Konstantopoulou et al., 2019). 


\section{Hypothesis Development}

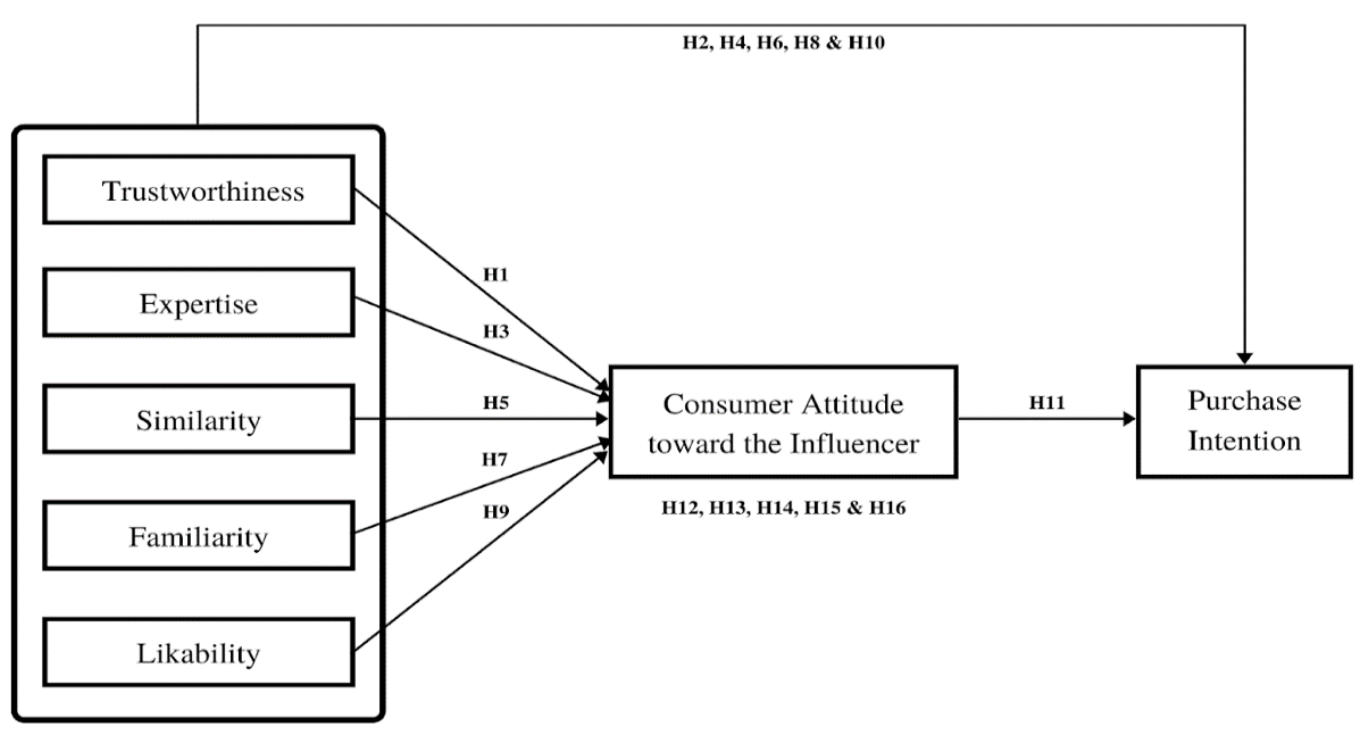

Figure 1. Conceptual Framework

H1 . Trustworthiness positively influences the consumers' attitude towards the influencer.

$\mathrm{H} 2$. Trustworthiness positively influences customers' purchase intention.

H3. Expertise positively influences the consumers' attitude towards the influencer.

H4. Expertise positively influences customers' purchase intention.

H5. Similarity positively influences the consumers' attitude towards the influencer.

H6. Similarity positively influences customers' purchase intention.

H7. Familiarity positively influences the consumers' attitude towards the influencer.

H8. Familiarity positively influences customers' purchase intention.

H9. Likability positively influences the consumers' attitude towards the influencer.

H10. Likability positively influences customers' purchase intention.

H11. Consumers' attitude toward the influencer positively influences purchase intention.

H12. Consumer attitude towards the influencer mediates the relationship between trustworthiness and purchase intention

H13. Consumer attitude towards the influencer mediates the relationship between expertise and purchase intention

H14. Consumer attitude towards the influencer mediates the relationship between similarity and purchase intention

H15. Consumer attitude towards the influencer mediates the relationship between familiarity and purchase intention

H16. Consumer attitude towards the influencer mediates the relationship between likability and purchase intention

\section{Methodology}

\section{Research Approach}

Quantitative research approach is being adopted to implement this research. This research wants to identify the relationship between the independent and dependent variables. Due to quantitative methods specifically focusing on statistical numbers and analysis, this aids Copyright $\odot$ GLOBAL ACADEMIC EXCELLENCE (M) SDN BHD - All rights reserved 
Volume 3 Issue 9 (September 2021) PP. 209-227

DOI 10.35631/AIJBES.39015

hypothesis testing and the ground to further enhance generalizable data within the subject (Bryman and Bell, 2019). Therefore, a quantitative research approach is suitable for this research.

\section{Research Method}

This research will make use of primary data, which is information gathered for the first time by the researcher. Surveys is used to obtain data from respondents in order to collect statistical information. The survey method's goal is to generate potential arguments among the variables in this study for a specific relationship (Saunders et al., 2008). Questionnaires will be used to obtain data from respondents in order to collect statistical information and respondents were asked to evaluate each proposed statement by using five-point Likert scale.

\section{Population}

This research focuses on the respondents who are female university students in Bandung, Indonesia with knowledge about social media influencers especially who are promoting fashion items and daily social media users. Based on the marketing research book by Malhotra (2010), researchers can apply a minimum of 200 respondents to be the sample size in conducting marketing research studies. Therefore, questionnaires were distributed to more than 250 respondents and 234 respondents are used as it fulfil the qualification.

\section{Sampling Technique}

This research adopted non-probability sampling, specifically a judgmental sampling which researchers rely on personal judgment when choosing members of the population to participate in the study (Tongco, 2007). This study needs to focus on particular characteristics of respondents which in this research are university students (Undergraduate) in Bandung with knowledge about social media influencers especially who are promoting fashion items and daily social media users. Therefore, purposive sampling is chosen which is best enable researchers to get the answer of research questions through the right targeted respondent. After all usable data has been gathered, data analysis proceeds. Data obtained by the researcher will be analyzed using the Regression Analysis Method through IBM SPSS Statistics software. 


\section{Result and Analysis}

\section{Demographic Profile}

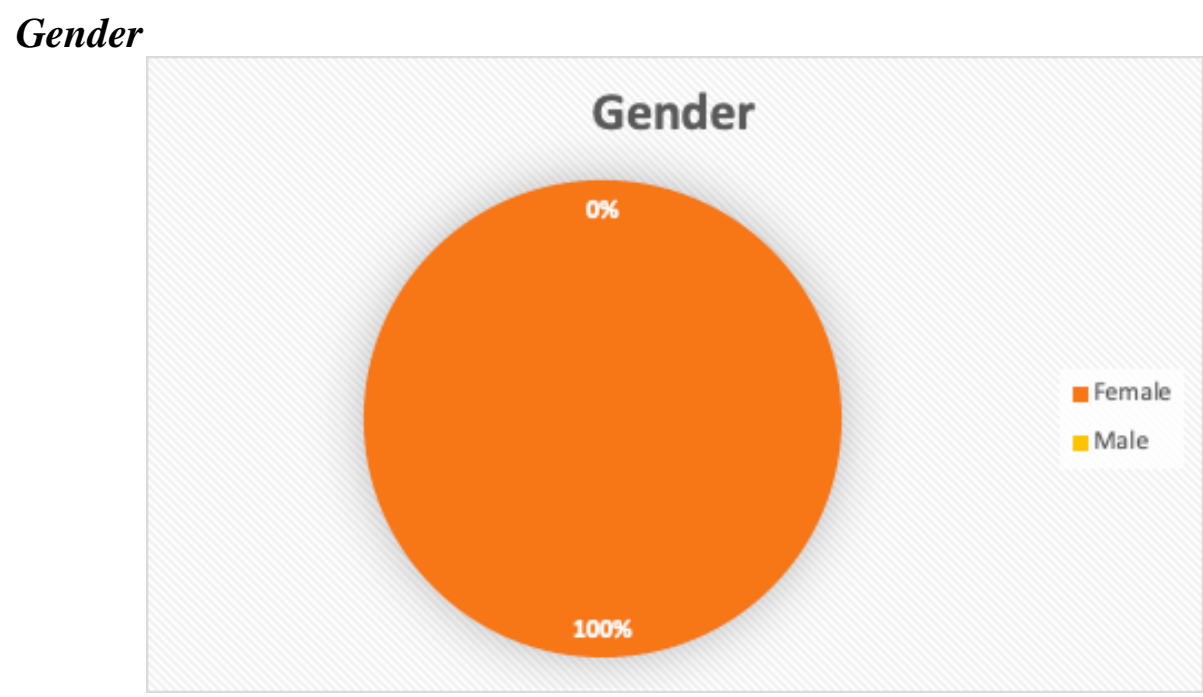

Figure 2. Gender

Figure 2 shows that this research collected responses only from female respondents with a total of 234 respondents. This meets the requirement of the research since it specifically wants to acknowledge the factors within Fashion Influencer would influence purchase intention of female university students.

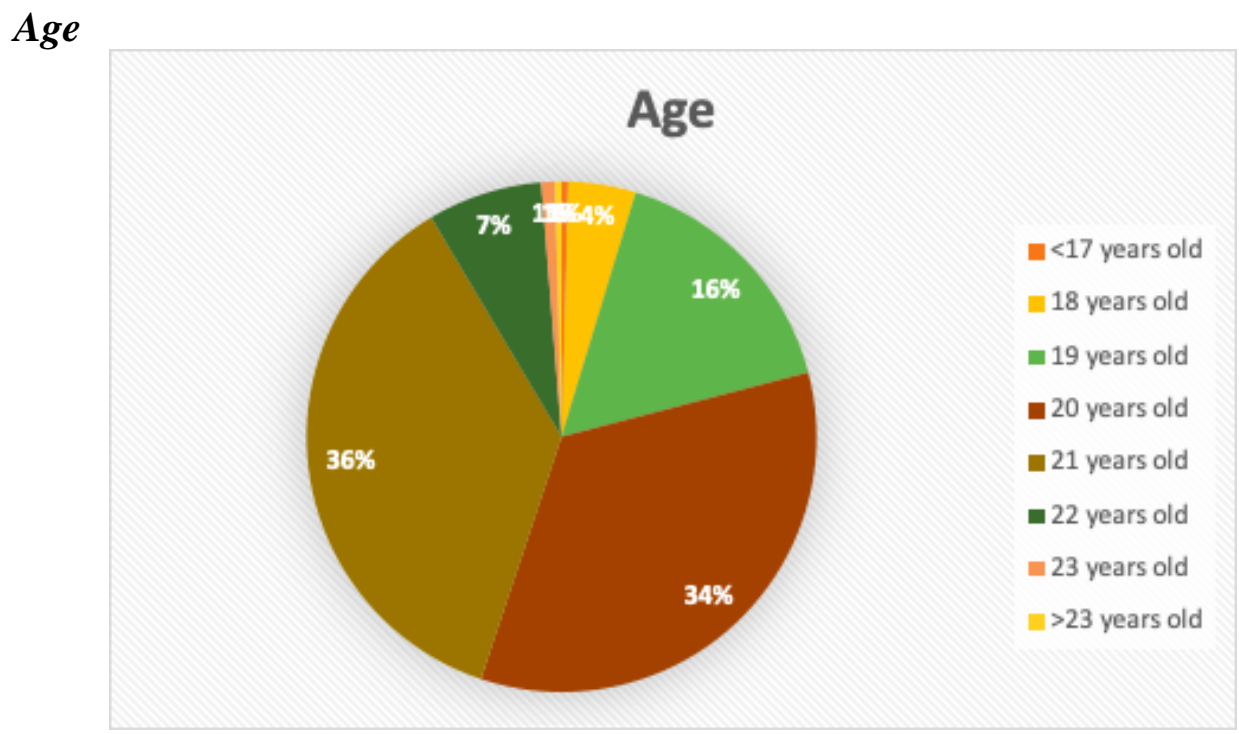

Figure 3. Age

Figure 3 presents that from the total of 234 female respondents, there are 85 respondents (36.3\%) aged 21 years old, 80 respondents (34.2\%) aged 20 years old, 38 respondents aged 19 years old (16.2\%), 17 respondents $(7.3 \%)$ aged 22 years old, 10 respondents $(4.3 \%)$ aged 18 years old, 2 respondents $(0.9 \%)$ aged 23 years old, one respondents $(0.4 \%)$ aged below 17 years old, and one respondents $(0.4 \%)$ aged above 23 years old. The result indicates the data did not 
Volume 3 Issue 9 (September 2021) PP. 209-227

DOI 10.35631/AIJBES.39015

heavily rely on specific age, rather show different ranges of age within the average age of university students.

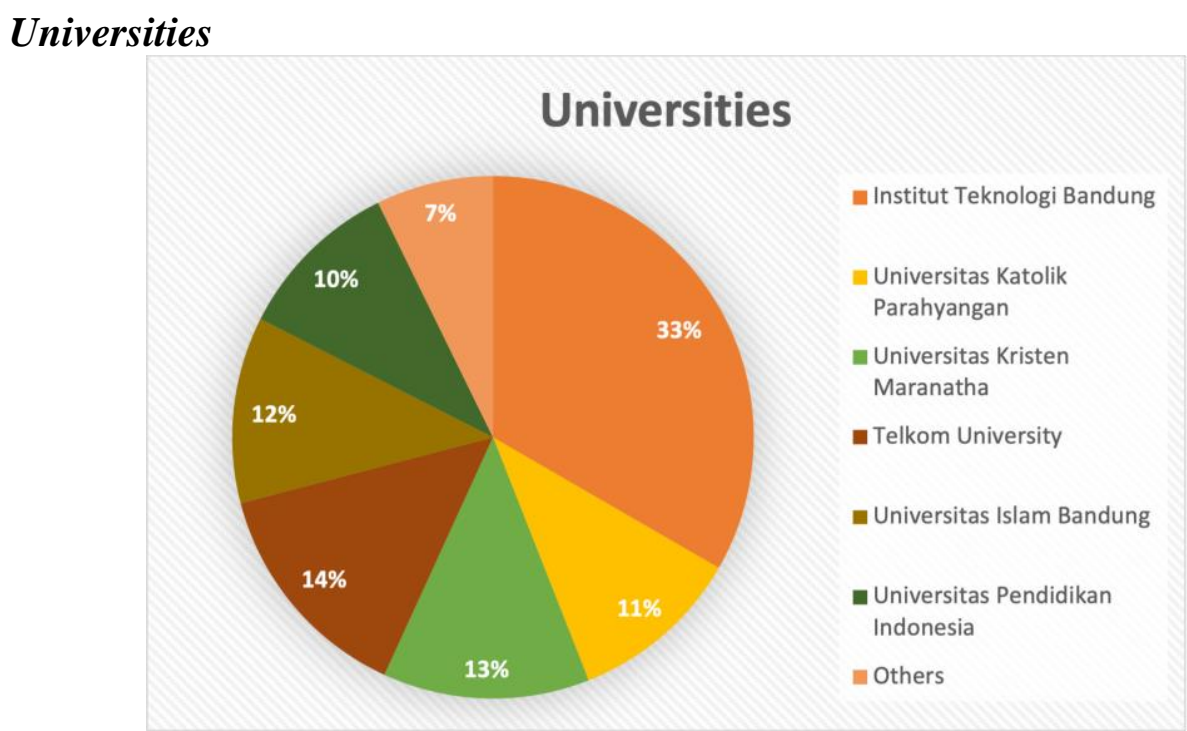

Figure 4. Universities

Figure 4 presents which university in Bandung the respondents come from. From total 234 female university students who participated in the survey, 78 respondents $(33.3 \%)$ from Bandung Institute of Technology, 33 respondents (14.1\%) from Telkom University, 30 respondents (12.8\%) from Universitas Kristen Maranatha, 27 respondents (11.5\%) from Universitas Islam Bandung, 25 respondents (10.7\%) from Universitas Katolik Parahyangan, 24 respondents $(10.3 \%)$ from Universitas Pendidikan Indonesia, and 17 respondents $(7.3 \%)$ are from another universities in Bandung that has been previously mentioned such as Universitas Pasundan, Universitas Komputer Indonesia, Universitas Jenderal Achmad Yani, Politeknik Negeri Bandung, Universitas Sangga Buana YPKP, Politeknik STIA LAN Bandung, and Universitas Langlang Buana. The result indicates the data did not heavily rely on specific university, rather show the respondents are comes from several university.

\section{Validity and Reliability of Research Instruments}

The validity test is conducted using Pearson Correlation Coefficient through the SPSS program. If the values of $\mathrm{R}$ arithmetic are more than the $\mathrm{R}$ table and show a positive value, the question will be considered as valid to be used in this research. The $\mathrm{R}$ table value being used to test 234 respondents is 0.124 ( $\mathrm{R}$ table for 250 respondents with $95 \%$ confidence level). Hence, if the correlation coefficient of the items is bigger than 0.124 , the question is considered valid.

Table 1. Validity Test

\begin{tabular}{|c|c|c|c|}
\hline Variables & Items & $\begin{array}{c}\text { Pearson } \\
\text { Correlation }\end{array}$ & Validity \\
\hline \multirow{2}{*}{ Trustworthiness } & TR1 & 0.587 & Valid \\
\cline { 2 - 4 } & TR2 & 0.566 & Valid \\
\cline { 2 - 4 } & TR3 & 0.518 & Valid \\
\hline
\end{tabular}


Volume 3 Issue 9 (September 2021) PP. 209-227

DOI 10.35631/AIJBES.39015

\begin{tabular}{|c|c|c|c|}
\hline & TR4 & 0.575 & Valid \\
\hline \multirow[t]{4}{*}{ Expertise } & EXP1 & 0.526 & Valid \\
\hline & EXP2 & 0.572 & Valid \\
\hline & EXP3 & 0.572 & Valid \\
\hline & EXP4 & 0.485 & Valid \\
\hline \multirow[t]{3}{*}{ Likability } & LIKE1 & 0.536 & Valid \\
\hline & LIKE2 & 0.581 & Valid \\
\hline & LIKE3 & 0.566 & Valid \\
\hline \multirow[t]{3}{*}{ Similarity } & SIM1 & 0.623 & Valid \\
\hline & SIM2 & 0.686 & Valid \\
\hline & SIM3 & 0.658 & Valid \\
\hline \multirow[t]{4}{*}{ Familiarity } & FAM1 & 0.596 & Valid \\
\hline & FAM2 & 0.571 & Valid \\
\hline & FAM3 & 0.577 & Valid \\
\hline & FAM4 & 0.560 & Valid \\
\hline \multirow{4}{*}{$\begin{array}{l}\text { Attitude toward } \\
\text { Influencers }\end{array}$} & ATT1 & 0.675 & Valid \\
\hline & ATT2 & 0.573 & Valid \\
\hline & ATT3 & 0.628 & Valid \\
\hline & ATT4 & 0.672 & Valid \\
\hline \multirow[t]{3}{*}{ Purchase Intention } & PI1 & 0.659 & Valid \\
\hline & PI2 & 0.548 & Valid \\
\hline & PI3 & 0.626 & Valid \\
\hline
\end{tabular}

According to the table above, the correlation coefficient of all items of questions is greater than the $\mathrm{R}$ table. Therefore, all the data collected in this research is known as valid data.

For reliability test, this research used Cronbach's Alpha through SPSS program. Items with Cronbach's Alpha value more than 0.6 will be considered as reliable to be used in this research. 
Table 2. Reliability Test Individual Value

\begin{tabular}{|c|c|c|c|}
\hline Variables & Items & $\begin{array}{c}\text { Cronbach's } \\
\text { Alpha }\end{array}$ & Reliability \\
\hline \multirow[t]{4}{*}{ Trustworthiness } & TR1 & 0.917 & Reliable \\
\hline & TR2 & 0.917 & Reliable \\
\hline & TR3 & 0.918 & Reliable \\
\hline & TR4 & 0.917 & Reliable \\
\hline \multirow[t]{4}{*}{ Expertise } & EXP1 & 0.918 & Reliable \\
\hline & EXP2 & 0.917 & Reliable \\
\hline & EXP3 & 0.917 & Reliable \\
\hline & EXP4 & 0.918 & Reliable \\
\hline \multirow[t]{3}{*}{ Likability } & LIKE1 & 0.918 & Reliable \\
\hline & LIKE2 & 0.917 & Reliable \\
\hline & LIKE3 & 0.917 & Reliable \\
\hline \multirow[t]{3}{*}{ Similarity } & SIM1 & 0.916 & Reliable \\
\hline & SIM2 & 0.915 & Reliable \\
\hline & SIM3 & 0.916 & Reliable \\
\hline \multirow[t]{4}{*}{ Familiarity } & FAM1 & 0.917 & Reliable \\
\hline & FAM2 & 0.918 & Reliable \\
\hline & FAM3 & 0.917 & Reliable \\
\hline & FAM4 & 0.917 & Reliable \\
\hline \multirow{4}{*}{$\begin{array}{l}\text { Consumers' } \\
\text { attitude toward } \\
\text { Influencers }\end{array}$} & ATT1 & 0.915 & Reliable \\
\hline & ATT2 & 0.917 & Reliable \\
\hline & ATT3 & 0.916 & Reliable \\
\hline & ATT4 & 0.916 & Reliable \\
\hline \multirow{3}{*}{$\begin{array}{l}\text { Purchase } \\
\text { Intention }\end{array}$} & PI1 & 0.916 & Reliable \\
\hline & PI2 & 0.918 & Reliable \\
\hline & PI3 & 0.916 & Reliable \\
\hline
\end{tabular}


Higher Cronbach's Alpha value indicates higher reliability. According to the table above, as each item has Cronbach's Alpha value more than 0.6, this research provides reliable data.

\section{Regression Analysis}

This section depicts the empirical findings obtained from the collected data of the study. Table 1 shows significancy and the strength of relationship examines in $\mathrm{H} 1, \mathrm{H} 3, \mathrm{H} 5, \mathrm{H} 7$, and $\mathrm{H}$ 9.

Table 3. Coefficient Table 1

\begin{tabular}{|l|l|l|l|l|l|l|}
\hline Hypothesis & Relationship & $\begin{array}{c}\text { Coefficients Std. } \\
\text { Error }\end{array}$ & $\begin{array}{c}\text { Std. Beta } \\
(\mathrm{B})\end{array}$ & t-value & Sig. & Result \\
\hline H1 & TR -> ATT & .056 & .138 & 2.285 & .023 & Significant \\
\hline H3 & $\begin{array}{l}\text { EXP -> } \\
\text { ATT }\end{array}$ & .054 & .281 & 5.162 & .000 & Significant \\
\hline H5 & $\begin{array}{l}\text { SIM -> } \\
\text { ATT }\end{array}$ & .045 & .282 & 4.496 & .000 & Significant \\
\hline H7 & $\begin{array}{l}\text { FAM -> } \\
\text { ATT }\end{array}$ & 0.48 & .085 & 1.392 & .165 & $\begin{array}{l}\text { Not } \\
\text { Significant }\end{array}$ \\
\hline H9 & $\begin{array}{l}\text { LIKE -> } \\
\text { ATT }\end{array}$ & .050 & .173 & 3.136 & .002 & Significant \\
\hline
\end{tabular}

Based on Table 1, the result illustrated that the p-value of trustworthiness is 0.023 , expertise is 0.000 , similarity is 0.000 , likability is 0.002 , and familiarity is 0.165 . In this case, trustworthiness, expertise, similarity, and likability shows a significant relationship to consumer attitude towards the influencer because they have a significance value less than 0.05 . Moreover, the result in Table 4.7 illustrated that the std. beta value of similarity is 0.282 which indicates that similarity is the strongest contributor in explaining the consumer attitude towards the influencer.

Next, Table 2 shows significancy and the strength of relationship examines in H2, H4, H6, H8, and $\mathrm{H} 10$.

Table 2. Coefficient Table 2

\begin{tabular}{|l|l|l|l|l|l|l|}
\hline Hypothesis & Relationship & $\begin{array}{c}\text { Coefficients Std. } \\
\text { Error }\end{array}$ & $\begin{array}{c}\text { Std. Beta } \\
(\mathrm{B})\end{array}$ & t-value & Sig. & \multicolumn{1}{|c|}{ Result } \\
\hline H2 & TR -> PI & .088 & .183 & 2.633 & .009 & Significant \\
\hline H4 & EXP -> PI & .084 & .013 & .206 & .837 & $\begin{array}{l}\text { Not } \\
\text { Significant }\end{array}$ \\
\hline H6 & SIM -> PI & .071 & .206 & 2.860 & .005 & Significant \\
\hline H8 & FAM -> PI & .075 & .166 & 2.369 & .019 & Significant \\
\hline
\end{tabular}


Volume 3 Issue 9 (September 2021) PP. 209-227 DOI 10.35631/AIJBES.39015

\begin{tabular}{|l|l|l|l|l|l|l|}
\hline H10 & LIKE -> PI & .078 & .199 & 3.141 & .002 & Significant \\
\hline
\end{tabular}

Based on Table 2, the result illustrated that the p-value of trustworthiness is 0.009 , expertise is 0.837 , similarity is 0.005 , likability is 0.002 , and familiarity is 0.019 . In this case, trustworthiness, similarity, likability, and familiarity shows a significant relationship to purchase intention because they have a significance value less than 0.05 . Surprisingly, expertise shows insignificant relationships to purchase intention with significance value above 0.05 . The result in Table 4.8 illustrated that the std. beta value of similarity is 0.206 which indicates that similarity is the strongest contributor in explaining consumer purchase intention.

Next, Table 3 shows significancy and the strength of relationship examines in H11.

Table 3. Coefficient Table 3

\begin{tabular}{|l|l|l|l|l|l|l|}
\hline Hypothesis & Relationship & $\begin{array}{l}\text { Coefficients Std. } \\
\text { Error }\end{array}$ & $\begin{array}{l}\text { Std. Beta } \\
(\mathrm{B})\end{array}$ & t-value & Sig. & Result \\
\hline H11 & ATT -> PI & .072 & .598 & 11.358 & .000 & Significant \\
\hline
\end{tabular}

Table 3 shows that consumers' attitude towards the influencer has a significant relationship with purchase intention with a significance level of 0.000. Moreover, consumers' attitudes towards the influencers shows strong contribution to the purchase intention with a beta value of 0.598 .

Lastly, Table 4 shows the result whether attitudes towards the influencer proven to be mediating the relationship between trustworthiness, expertise, similarity, familiarity, likability and purchase intention.

Table 4. Mediating Result

\begin{tabular}{|c|c|c|c|c|c|c|}
\hline \multirow[t]{2}{*}{ Hypothesis } & \multirow[t]{2}{*}{ Relationship } & \multirow{2}{*}{$\begin{array}{c}\text { Indirect } \\
\text { Effect }\end{array}$} & \multirow{2}{*}{$\begin{array}{l}\text { Confidence } \\
\text { Interval }\end{array}$} & \multicolumn{2}{|c|}{ p-value } & \multirow[t]{2}{*}{ Result } \\
\hline & & & & $\begin{array}{l}\text { Total } \\
\text { Effect }\end{array}$ & $\begin{array}{l}\text { Direct } \\
\text { Effect }\end{array}$ & \\
\hline H12 & $\begin{array}{l}\text { TR -> ATT - } \\
>\text { PI }\end{array}$ & .3225 & $(.0507-.4292)$ & .0000 & .0007 & Supported \\
\hline H13 & $\begin{array}{l}\text { EXP } \rightarrow \text { ATT } \\
\rightarrow>\text { PI }\end{array}$ & .4474 & $(.3329-.5727)$ & .0000 & .6322 & Supported \\
\hline $\mathrm{H} 14$ & $\begin{array}{l}\text { SIM -> ATT } \\
->\text { PI }\end{array}$ & .3051 & $(.2150-.4125)$ & .0000 & .0050 & Supported \\
\hline H15 & $\begin{array}{l}\text { FAM -> ATT } \\
->\text { PI }\end{array}$ & .2470 & $(.1704-.3341)$ & .0000 & .0002 & Supported \\
\hline H16 & $\begin{array}{l}\text { LIKE -> } \\
\text { ATT -> PI }\end{array}$ & .2685 & $(.1893-.3568)$ & .0000 & .0016 & Supported \\
\hline
\end{tabular}


Volume 3 Issue 9 (September 2021) PP. 209-227 DOI 10.35631/AIJBES.39015

Based on Table 4, the relationships explained in H12, H13, H14, H15, H16 have shown a positive value of indirect effect that is $0.3225,0.4474,0.3051,0.2470$, and 0.2685 respectively. It indicates that consumer attitude towards the relationship has a significant effect in mediating the relationship between the trustworthiness, expertise, similarity, familiarity, and likability to purchase intention.

\section{Discussion}

\section{There Is a Significant Influence Between Trustworthiness to Consumers' Attitudes Towards the Influencer and Purchase Intention}

This study revealed significant relationships between trustworthiness on consumers' attitude towards the influencer and purchase intention ( $\mathrm{HI}$ and $\mathrm{H} 2$ were valid). This relationship is supported by the study of Chetioui et al. (2019). In this research, respondents believed the influencers are providing accurate information about the product being endorsed and they can rely on the influencer through their product recommendations to make purchasing decisions. It creates a positive attitude towards the influencers and subsequently influences their purchase intention toward the product that is recommended or promoted by the influencer. Moreover, consumers' attitude towards the influencer also proved to be a partial mediator between relationships of trustworthiness and purchase intention (H12 is accepted). Consumers could be influenced to purchase the product directly through the fashion influencer honesty and sincerity, however the consumer perceptions and belief toward particular behavior of the influencer proved to be intermediating the relationships.

There Is a Significant Influence Between Expertise to Consumers'Attitudes Towards the Influencer and Insignificant Influence Between Expertise to Purchase Intention

Expertise is proven to have a positive impact on consumers towards the influencer (H3 is valid). Which is relevant to previous study by Chetioui et al. (2019). Surprisingly, expertise was found to have insignificant influence on purchase intention ( $\mathrm{H} 4$ is rejected). In this research, respondents believed fashion influencers are indeed an expert in the fashion field. They also believe that the influencers have a certain ability to demonstrate the fashion items that are being endorsed. However, respondents acknowledged the influencer expertise only influences positive perceptions towards the influencer and not enough to give a certain impact to consumer intention to purchase a product being endorsed by the influencer without the involvement of certain variables. In this study, expertise is revealed as the least contributor to purchase intention which shows different result as Chun et al. (2018), Chetioui et al. (2019), Lou \& Yuan (2019) that revealed expertise have significant influence to purchase intention. Even though the research's subject of the stated previous is younger generations especially generation $\mathrm{Z}$ which similar to this research. However, consumers' attitude towards the influencer proved to be a full mediator between relationships of fashion influencer's expertise and purchase intention (H13 is accepted). It indicates the possibility of the consumer to purchase an endorsed product due to the influence of the fashion influencer's expertise with an involvement of consumer towards the influencer as the intermediate effect between them.

\section{There Is a Significant Influence Between Similarity to Consumers' Attitudes Towards the Influencer and Purchase Intention}

This study revealed significant relationships between similarity on consumers' attitude towards the influencer and purchase intention (H5 and $\mathrm{H} 6$ were valid). The result is relevant to the study by Chun, Lim, Tan, Teh (2018) and Zainab et al., (2020). This study revealed the feeling of having something in common with the fashion influencer such as similar fashion style, similar Copyright (C) GLOBAL ACADEMIC EXCELLENCE (M) SDN BHD - All rights reserved 
Volume 3 Issue 9 (September 2021) PP. 209-227 DOI 10.35631/AIJBES.39015

taste in fashion product, or similar interest or hobbies success to influence consumer purchasing decision towards the product being endorsed. This study also revealed similarity as the strongest factor in contributing to both consumer attitude towards the influencer and purchasing intention. Moreover, consumers' attitude towards the influencer also proved to be a partial mediator between relationships of similarity and purchase intention (H14 is accepted). Consumers could be influenced to purchase the product directly through the fashion influencer similarities especially in fashion style with the consumer, however the consumer perceptions and belief toward particular behavior of the influencer proved to be intermediating the relationships.

\section{There Is an Insignificant Influence Between Familiarity to Consumers'Attitudes Towards the Influencer and Significant Influence Between Familiarity to Purchase Intention}

Familiarity emerged through the recognition of the influencer by the exposure or previous association and familiarity provides the audience a sense of comfort, the feeling of intimacy and closeness makes the audience accept the influencer's advice on making a best product selection and it leads to significant influence in the consumers' purchase decision (Martensen et al. 2018). However, the result found familiarity failed to influence the consumer attitudes towards the influencer ( $\mathrm{H} 7$ is rejected). It is revealed as the least factor that contributes to consumer attitude towards the influencer. While familiarity is found to influence the consumer intention to purchase an endorsed product ( $\mathrm{H} 8$ is valid), which is relevant to the study by Martensen et al., 2018). Moreover, consumers' attitude towards the influencer also proved to be a mediator between relationships of familiarity and purchase intention (H15 is accepted). This result indicates respondents' opinion that in order to have a positive attitude and perceptions towards the influencer, it is unnecessary to feel familiar towards the influencer. However, even though familiarity is unnecessary to encourage the consumer attitude towards the influencer, if the end of purpose is the purchase intention, consumer attitude the influencer happens to exist as the mediating factor.

\section{There Is a Significant Influence Between Likability to Consumers' Attitudes Towards the Influencer and Purchase Intention}

This study revealed significant relationships between likability on consumers' attitude towards the influencer and purchase intention (H9 and $\mathrm{H} 10$ were valid). In this study, respondents acknowledged the fashion influencer they know as someone who is physically attractive and has an appealing personality. Attractive individuals are most likely to get more attention in which customers bond to have a positive attitude towards their favourable influencer. Consumers like to imitate the social media influencers by making purchases similar to that used by their favorite influencers (Djafarova and Rushworth, 2017). Moreover, consumers' attitude towards the influencer also proved to be a partial mediator between relationships of likability and purchase intention (H16 is accepted). Consumers can be influenced to purchase the product directly through the fashion influencer's attractive features and personality, however the consumer perceptions and belief toward particular behavior of the influencer proved to be intermediating the relationships. As a result, influencers with appealing appearances and characteristics favorably impact consumers' attitudes about the influencers, which in turn influences their purchase intention (Lim et al., 2017). 
Volume 3 Issue 9 (September 2021) PP. 209-227

DOI 10.35631/AIJBES.39015

There Is a Significant Influence Between Consumers' Attitude Towards the Influencer and Purchase Intention

Consumers attitude towards the influencer is revealed to influence the consumers' purchase intention (H11 is valid). In this study, respondents acknowledge the fashion influencer they know as someone who is presenting interesting content, providing new deals about different products and services, and as a reliable source of information and discovery. According to the findings of this study, consumers who have a positive attitude and perception toward particular behavior of the social media influencers are more likely to want to purchase the product endorsed by the influencer. This statement was also proved in study by (Lim et al., 2017). Moreover, consumers' attitudes towards the influencers shows strong contribution to the purchase intention with a beta value of 0.598 . The strong contribution of consumers' attitudes towards the influencers to the consumers' purchase intention also supported the reason for consumers' attitude towards the influencer successfully mediating all the independent variables examined in this research. This significant relationship indicates the influencer marketing as a viable alternative for fashion brands to escalate awareness of their product and brands, increase the market share, and drive the purchase intention of existing and new consumers.

\section{Conclusion}

As today's fashion industry works in a dynamic unpredictable setting, more social media influencers become involved in promotional activities, it's more crucial than ever to completely comprehend how these processes are affecting the industry. Because the influencers keep up with the newest trends in their fields, they have a leg up on their audience in terms of knowing what they want and what they are intent to purchase. The fashion influencer proposed values and unique characters to appear more appealing in terms of promoting products from the fashion brand. Therefore, this study objective is to identify what kind of factors within the fashion influencer would significantly influence the customers' attitude towards the influencer and purchase intention. Furthermore, this research examines the possibility of whether customers' attitudes towards the influencer mediate the factors within the fashion influencer in order to successfully construct the purchase intention.

This study has revealed that trustworthiness, expertise, similarity, and likability shows a significant relationship to consumers' attitude towards the influencer. This indicates that consumers acknowledge the sincerity, ability to demonstrate product in the specific field, similar preferences, and attractive individuals could develop positive assumptions towards the influencer. Based on the result, trustworthiness, similarity, familiarity, and likability significantly contribute to influencing consumers' intention to purchase the product being endorsed by the influencer. This indicates that consumers are more likely to purchase fashion items being endorsed by influencers if the consumer finds they can trust the recommendations, they feel similarity in style and common things with the influencers, they feel intimacy to familiar influencers, and if they attract to their appealing features to the point that they want to have similar product to influencers. Surprisingly, in this research, expertise failed to affect consumers' purchase intention, which is irrelevant to previous study by Chun et al. (2018), Chetioui et al. (2019), Lou \& Yuan (2019) that revealed expertise have significant influence to purchase intention. Even though the research's subject of the stated previous is younger generations especially generation $\mathrm{Z}$ which similar to this research.

Consumers' attitude towards the influencer further shows strong significant influence to consumers' purchase intention. Respondents acknowledge the fashion influencer they know as someone who is presenting interesting content, providing new deals about different products 
Volume 3 Issue 9 (September 2021) PP. 209-227

DOI 10.35631/AIJBES.39015

and services, and as a reliable source of information and discovery. Moreover, consumers' attitude towards the influencer found to intermediate the correlation between all the independent variables to purchase intention.

Through this analysis in this research, it can be concluded that fashion influencers play a major role in the fashion industry by shaping the consumers' purchase decisions. It found that more than eighty eight percent of the respondents have been persuaded to purchase a fashion product due to the promotional and recommendation done by the fashion influencer. Therefore, endorsing the fashion influencer has proven to become promising marketing strategies in the fashion industry to drive consumer intention to purchase the product being endorsed.

\section{Limitation and Future Research}

This research only examines trustworthiness, expertise, similarity, likability, and familiarity as possible factors in contributing to consumers' attitude toward the influencer and purchase intention. Nevertheless, it is crucial to highlight that other possible aspects such as communication, perceived congruence, integration, and the perspectives of influencers were not included in this study. Moreover, this research only involves female respondents since a previous research stated that female respondents are most likely to use online reviews and recommendations on the product they want to purchase. Further, this research only involves university students specifically in Bandung which the average belongs to the Z-gen and on average has not earned an income of its own. Therefore, future research suggested expanding the target respondents to not only females but also male respondents and suggested to examine different demographics of target respondents. As a result, further research could be examined with an enlargement of sample and an expanded theoretical framework.

\section{References}

Aragoncillo, L., \& Orus, C. (2018). Impulse buying behaviour: an online-offline comparative and the impact of social media. Spanish Journal Of Marketing - ESIC, 22(1), 42-62.

Bianchi, C., Andrews, L., Wiese, M., \& Fazal-E-Hasan, S. (2017). Consumer intentions to engage in s-commerce: a cross-national study. Journal Of Marketing Management, 131.

Braatz, L. (2021). \#Influencer marketing on instagram : consumer responses towards promotional posts: the effects of message sidedness - University of Twente Student Theses. Retrieved from http://purl.utwente.nl/essays/72365.

Bryman, A. and Bell, E., 2011. Business Research Methods. 3rd ed. Oxford: Oxford Univ. Press.

Cheong, H., \& Morrison, M. (2008). Consumers' Reliance on Product Information and Recommendations Found in UGC. Journal Of Interactive Advertising, 8(2), 38-49.

Chetioui, Y., Benlafqih, H., \& Lebdaoui, H. (2020). How fashion influencers contribute to consumers' purchase intention. Journal Of Fashion Marketing And Management: An International Journal, 24(3), 361-380.

Cheung, C., Lee, M., \& Rabjohn, N. (2008). The impact of electronic word-of- mouth. Internet Research, 18(3), 229-247.

Colliander, J., \& Dahlén, M. (2011). Following the Fashionable Friend: The Power of Social Media. Journal Of Advertising Research, 51(1), 313-320.

Conn, V. (2009). Celebrity Endorsement of Meta-Analysis?. Western Journal Of Nursing Research, 31(4), 435-436. 
Volume 3 Issue 9 (September 2021) PP. 209-227

DOI 10.35631/AIJBES.39015

Djafarova, E., \& Rushworth, C. (2017). Exploring the credibility of online celebrities' Instagram profiles in influencing the purchase decisions of young female users. Computers In Human Behavior, 68, 1-7.

Gazzola, P., Pavione, E., Pezzetti, R., \& Grechi, D. (2020). Trends in the Fashion Industry. The Perception of Sustainability and Circular Economy: A Gender/Generation Quantitative Approach. Sustainability, 12(7), 2809.

Huang, Y., Jim Wu, Y., Wang, Y., \& Boulanger, N. (2011). Decision making in online auctions. Management Decision, 49(5), 784-800.

Johnson, T., Kaye, B., Bichard, S., \& Wong, W. (2007). Every Blog Has Its Day: Politicallyinterested Internet Users' Perceptions of Blog Credibility. Journal Of ComputerMediated Communication, 13(1), 100-122.

Kapitan, S. and Silvera, D. H. (2016) 'From digital media influencers to celebrity endorsers: attributions drive endorser effectiveness', Marketing Letters, 27(3), pp. 553-567. doi: 10.1007/s11002-015-9363-0.

Kelman, H. (1961). Processes of Opinion Change. Public Opinion Quarterly, 25(1), 57.

Khatri, P. (2006). Celebrity endorsement - A strategic promotion perspective. Indian Media Studies Journal, 1(1), 25-37.

Konstantopoulou, A., Rizomyliotis, I., Konstantoulaki, K., \& Badahdah, R. (2019). Improving SMEs' competitiveness with the use of Instagram influencer advertising and eWOM. International Journal Of Organizational Analysis, 27(2), 308-321.

Lafferty, B., Goldsmith, R., \& Newell, S. (2002). The Dual Credibility Model: The Influence of Corporate and Endorser Credibility on Attitudes and Purchase Intentions. Journal Of Marketing Theory And Practice, 10(3), 1-11.

Lang, C., \& Armstrong, C. (2018). Fashion leadership and intention toward clothing productservice retail models. Journal Of Fashion Marketing And Management: An International Journal, 22(4), 571-587.

Leather, P., McKechnie, S., \& Amirkhanian, M. (1994). The Importance of Likeability as a Measure of Television Advertising Effectiveness. International Journal of Advertising, 13(3), 265-280.

Lee, J., Park, D. H. and Han, I. (2011) 'The different effects of online consumer reviews on consumers' purchase intentions depending on trust in online shopping malls: An advertising perspective', Internet Research, 21(2), pp. 187-206.

Lee, Z., \& Yurchisin, J. (2011). The impact of website attractiveness, consumer-website identification, and website trustworthiness on purchase intention. International Journal Of Electronic Customer Relationship Management, 5(3/4), 272.

Liljander, V., Gummerus, J., \& Söderlund, M. (2015). Young consumers' responses to suspected covert and overt blog marketing. Internet Research, 25(4), 610-632.

Liu, S., Jiang, C., Lin, Z., Ding, Y., Duan, R., \& Xu, Z. (2015). Identifying effective influencers based on trust for electronic word-of-mouth marketing: A domain-aware approach. Information Sciences, 306, 34-52.

Malhotra, N. K. (2010). Marketing Research : An Applied Orientation. 6th ed. Upper Saddle River, NJ: Pearson Education.

Martensen, A., Brockenhuus-Schack, S. and Zahid, A. L. (2018) 'How citizen influencers persuade their followers', Journal of Fashion Marketing and Management, 22(3), pp. 335-353.

Nejad, M., Sherrell, D., \& Babakus, E. (2014). Influentials and Influence Mechanisms in New Product Diffusion: An Integrative Review. Journal of Marketing Theory And Practice, 22(2), 185-208. 
Volume 3 Issue 9 (September 2021) PP. 209-227 DOI 10.35631/AIJBES.39015

Ohanian, R. (1990). Construction and Validation of a Scale to Measure Celebrity Endorsers' Perceived Expertise, Trustworthiness, and Attractiveness. Journal of Advertising, 19(3), 39-52.

O'Reilly, K., \& Marx, S. (2011). How young, technical consumers assess online WOM credibility. Qualitative Market Research: An International Journal, 14(4), 330-359.

Park, H., \& Kim, Y. (2016). Proactive versus reactive apparel brands in sustainability: Influences on brand loyalty. Journal Of Retailing And Consumer Services, 29, 114-122.

Pate, S., \& Adams, M. (2013). The Influence of Social Networking Sites on Buying Behaviors of Millennials. Retrieved from https://digitalcommons.kennesaw.edu/amj/vol2/iss1/7

Pentina, I., Guilloux, V., \& Micu, A. (2018). Exploring Social Media Engagement Behaviors in the Context of Luxury Brands. Journal Of Advertising, 47(1), 55-69.

Piamphongsant, T., \& Mandhachitara, R. (2008). Psychological antecedents of career women's fashion clothing conformity. Journal Of Fashion Marketing And Management: An International Journal, 12(4), 438-455.

Ratneshwar, S., \& Chaiken, S. (1991). Comprehension's Role in Persuasion: The Case of Its Moderating Effect on the Persuasive Impact of Source Cues. Journal Of Consumer Research, 18(1), 52.

Saunders, M., Lewis, P. and Thornhill, A., 2009. Research Methods For Business Students. 5th ed. Edinburg: Pearson Education.

Schiffman, L., \& Wisenblit, J. (2000). Consumer behavior (7th ed.). Englewood Cliffs: Prentice-Hall.

Sudha, M., \& Sheena, K. (2017). Impact of Influencers in Consumer Decision Process: The Fashion Industry. SCMS Journal Of Indian Management, 14(3), 14-30.

Thakur, R., Angriawan, A. and Summey, J. H. (2016) . Technological opinion leadership: The role of personal innovativeness, gadget love, and technological innovativeness. Journal of Business Research, 69(8), 2768-2773.

Teng, S., Wei Khong, K., Wei Goh, W., \& Yee Loong Chong, A. (2014). Examining the antecedents of persuasive eWOM messages in social media. Online Information Review, 38(6), 746-768.

Thomas, T., \& Johnson, J. (2017). The Impact of Celebrity Expertise on Advertising Effectiveness: The Mediating Role of Celebrity Brand Fit. Vision: The Journal of Business Perspective, 21(4), 367-374.

Tongco, M. (2007). Purposive Sampling as a Tool for Informant Selection. Ethnobotany Research And Applications, 5, 147.

Tsang, A., \& Zhou, N. (2005). Newsgroup participants as opinion leaders and seekers in online and offline communication environments. Journal Of Business Research, 58(9), 11861193.

Wang, J., Cheng, Y., \& Chu, Y. (2012). Effect of Celebrity Endorsements on Consumer Purchase Intentions: Advertising Effect and Advertising Appeal as Mediators. Human Factors And Ergonomics In Manufacturing \& Service Industries, 23(5), 357-367.

Wang, K., Ting, I., \& Wu, H. (2013). Discovering interest groups for marketing in virtual communities: An integrated approach. Journal Of Business Research, 66(9), 13601366.

Xu (Rinka), X., \& Pratt, S. (2018). Social media influencers as endorsers to promote travel destinations: an application of self-congruence theory to the Chinese Generation Y. Journal Of Travel \& Tourism Marketing, 35(7), 958-972.

Zainab, A., Zahra, A., \& Shilan, R. (2020). Similarity, Familiarity, and Credibility in influencers and their impact on purchasing intention. Retrieved from http://www.divaportal.org/smash/record.jsf?pid=diva2:1437746

Copyright $\odot$ GLOBAL ACADEMIC EXCELLENCE (M) SDN BHD - All rights reserved 